\title{
Analisis Peran Wanita Generasi Milenial pada Usaha Mikro Kecil Menengah di dalam Era Ekonomi Digital di Kepulauan Riau Indonesia
}

\author{
Afrianti Elsye Vanomy* \\ Universitas Universal, Batam \\ Submitted Date : \\ 9 August 2021 \\ Sungai Panas, Kota Batam, Provinsi Kepri, 29444 \\ yanti.elva803@gmail.com \\ Accepted Date : \\ 5 November 2021 \\ Ibnu Harris \\ Universitas Universal, Batam \\ Sungai Panas, Kota Batam, Provinsi Kepri, 29444 \\ ibnu.harris@gmail.com
}

\section{Dibiayai oleh : \\ Kementerian Pendidikan Kebudayaan Riset dan Teknologi (Kemendikbudristek)}

Suggested Citation:

Nur Achmad S.E.,Msi dan Edi Purwo Saputro (2015). Faktor Sukses Wirausaha Wanita. FEB Unsoed :

https://jp.feb.unsoed.ac.id

Abstract:

This research can provide the illustration and answers about what millennial generation women must prepare who run MSME's. The research method is a quantitative approach, collecting data with questionaries and using purposive sampling, the study uses partial least square structural equation modelling analysis test. The amount of data used is 110 respondents. The object of research is the women entrepreneurs in Riau Islands who are in the age range of 21 to 41 years. The results of the study of discrimination factors, motivation, demographics had a significant positive effect on Capabilities, Commitment Factors, Financial Access Factors had a positive insignificant effect on Capabilities. Capability has a significant positive effect on MSME's Human capital, MSME's Human capital has a significant positive effect on the Digital Economy.

Keywords: Digital Economy; Millennial Generation; MSME

Abstrak:

Penelitian ini dapat memberikan gambaran dan jawaban tentang apa saja yang harus disiapkan oleh perempuan generasi milenial yang menjalankan UMKM. Metode penelitian adalah pendekatan kuantitatif, pengumpulan data dengan kuesioner dan menggunakan purposive sampling, penelitian menggunakan partial least square structural equation modelling. Jumlah data yang digunakan adalah 110 responden. Objek penelitian adalah para wanita pengusaha di Kepulauan Riau yang berada pada rentang usia 21 sampai dengan 41 tahun. Hasil penelitian faktor diskriminatif, motivasi, demografi berpengaruh positif signifikan terhadap Kapabilitas, Faktor Komitmen, Faktor Akses Keuangan berpengaruh positif tidak signifikan pada Kapabilitas. Capability berpengaruh positif signifikan terhadap Human capital UMKM, Human capital berpengaruh positif signifikan terhadap Digital Economy.

Keywords : Ekonomi Digital; Generasi Millenial; UMKM

JEL Classification: 015

${ }^{*}$ Corresponding Author 


\section{Latar Belakang}

Kata Wanita berasal dari bahasa sanskerta sama artinya dengan perempuan (Sutanto \& Haryoko, 2010). Tuhan menciptakan Wanita sebagai sosok yang mampu melakukan banyak hal sekaligus, peran tersebutlah yang akhirnya mampu mendorong seorang Wanita untuk mampu menyeimbangkan hidupnya dengan melakukan banyak peran sebagai seorang ibu, seorang wanita karir, bahkan hingga menjadi pemimpin dalam perusahaannya atau bisnisnya (Aluy dan Tulung, 2017). Peran wanita sejajar dengan pria di Indonesia, bahkan dalam berbagai macam kesempatan di dalam Pemerintahan maupun pendidikan serta karir. Sedangkan Indonesia perekonomiannya ditopang oleh Usaha Mikro Kecil Menengah (UMKM), hampir dari 60\% UMKM yang ada di Indonesia itu dimiliki oleh Wanita (Sutanto dan Haryoko, 2010). Sehingga peran Wanita dalam UMKM sudah tidak diragukan lagi, karena Wanita memiliki beberapa kelebihan dalam menjalankan bisnisnya yaitu seperti Wanita lebih banyak memiliki relasi dibandingkan pria, Wanita sangat jeli melihat peluang usaha,Wanita memang memiliki kelebihan untuk jauh lebih detail dan teliti karena terbiasa mengurusi hal-hal kecil sehingga ini sangat berharga sekali keahlian ini untuk menciptakan produk yang terlihat menarik sehingga memiliki daya jual yang tinggi, wanita sangat lihai dalam bertahan sehingga selalu menemukan cara agar bisnis UMKMnya akan terus berjalan (Bayu, 2011). Nilai lebih inilah yang membuat akhirnya UMKM yang diprakarsai Wanita terus berkembang produktif.

Indonesia sedang merambah ke masa baru yaitu demografi yang lebih dikenal sebagai era bonus demografi yang terjadi akibat perubahan komponen usia penduduk yang mana bisa dilihat dengan berkurangnya rasio perbandingan antara jumlah penduduk nonproduktif (umur kurang dari 15 tahun dan 65 tahun ke atas) terhadap jumlah penduduk produktif (usia 15-64 tahun) atau yang disebut sebagai rasio ketergantungan (dependency ratio). Bonus demografi adalah kejadian yang abnormal atau jarang ditemui karena hanya akan terjadi satu kali dalam histori sebuah kelompok masyarakat Ini mengingat bonus demografi terjadi ketika proporsi jumlah penduduk umur produktif posisinya berada di atas $2 / 3$ dari jumlah penduduk secara menyeluruh, atau dengan nama lain bonus demografi bisa terjadi ketika rasio ketergantungan angkanya berada di bawah 50 . Sebagian besar masyarakat yang berperan penting dalam bonus demografi adalah generasi milenial sehingga generasi milenial ini memiliki beban dan tanggungjawab yang besar dalam memegang kendali atas roda pembangunan khususnya dibidang perekonomian. menurut peneliti Kupperschmidt (2000) generasi atau angkatan adalah sekawanan pribadi yang menandai grupnya berasaskan kemiripan tahun kelahiran, usia, lokasi, dan kejadian-kejadian dalam kehidupan grup pribadi-pribadi tersebut yang mempunyai dampak begitu besar dalam tahapan perkembangan mereka. Pendapat lain melalui bukunya yang berjudul The Lucky Few: Between the Greatest Generation and the Baby Boom (2008), generasi milenial adalah mereka yang keberadaannya atau persalinannya dalam kurun waktu di tahun 1983 hingga 2001 (Carlson, 2008). Generasi milenial merupakan asset terbesar yang dimiliki Negara. (Badan Pusat Statistik, 2018)

Berikut ini adalah klasifikasi generasi berdasarkan pada tahun kelahirannya (Badan Pusat Statistik, 2018) :

Tabel 1. Klasifikasi Generasi berdasrkan Tahun Kelahiran

\begin{tabular}{cc} 
Tahun Kelahiran & Nama Generasi \\
\hline $1925-1946$ & Veteran Generation \\
$1946-1960$ & Baby Boom Generation \\
$1960-1980$ & X Generation \\
$1980-1995$ & Y Generation \\
$1995-2010$ & Z Generation \\
$2010+$ & Alfa Generation \\
\hline
\end{tabular}

Sumber: Putra (2016)

Di Indonesia usahawan wanita adalah penyumbang berharga untuk pembaharuan dan perkembangan ekonomii domestik. Sesuai dengan laporan statistik dari Badan Pusat Statistik, dari 2 juta unit usaha mikro, 40,8\% dikendalikan oleh wanita. Dari total 5,5 juta tenga kerja yang beroperasi di industri berukuran kecil dan industri rumahan, $45 \%$ dari tenaga kerja tersebut adalah wanita. The Asia Foundation memberitakan bahwa wanita merupakan pemilik $35 \%$ usaha kecil dan menengah (UKM) di Indonesia. Di wilayah Asia / Pasifik, Indonesia menduduki barisan terunggul dalam hal jumlah wanita sebagai empunya UKM, meskipun salah satu alasan tingginya kewirausahaan di golongan wanita bisa dihubungkan dengan rendahnya peluang kerja di sektor formal untuk wanita (Jamil, 2017). Berikut adalah prosentase UMKM berdasarkan pada klasifikasi jenis kelamin pengusaha tahun 2015 serta pengelompokan Usaha Mikro Kecil dan Menengah (UMKM) menurut UU No. 20 Tahun 2008. 
Gambar 1. Presentase UMKM berdasarkan pada klasifikasi jenis kelamin pengusaha tahun 2015

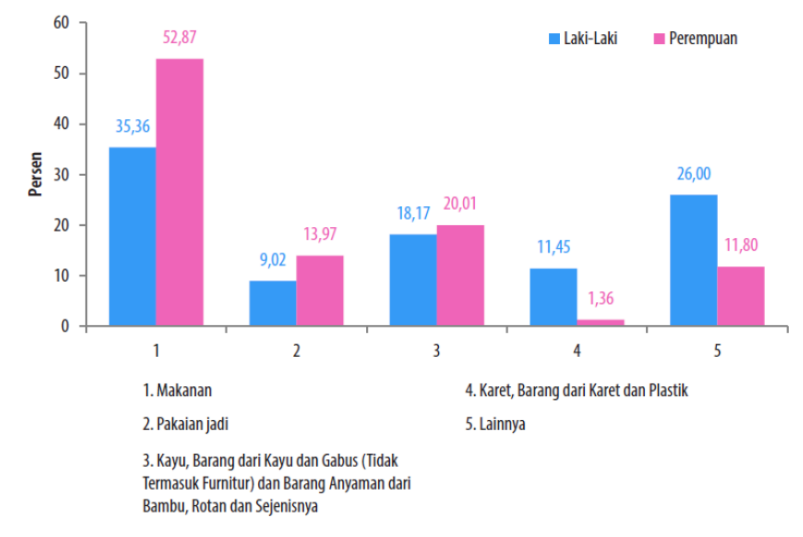

Sumber : Badan Pusat Statistik (2017)

Tabel 2. Pengelompokan UMKM menurtu UU No. 20 Tahun 2008

\begin{tabular}{rlll} 
No. & Usaha & \multicolumn{2}{c}{ Kriteria } \\
\cline { 3 - 4 } 1 & Usaha Mikro & & \multicolumn{1}{c}{ Aset } \\
2 & Usaha Kecil & Maksimal 50 Juta & Maksimal 300 Juta \\
3 & Usaha Menengah & $>50$ Juta -500 Juta & $>300$ Juta $-2,5$ Miliar \\
\hline
\end{tabular}

Sumber : Undang-Undang No. 20 Tahun 2008 Tentang Usaha Mikro, Kecil, Dan Menengah. Jakarta., (2008)

Human capital adalah tidak hanya berkutat pada sumber daya manusia pada institusi tapi lebih kepada apa yang diangkat oleh sumber daya manusia tersebut dan sumbangsihnya untuk mensukseskan institusi tersebut. Human capital sendiri adalah nilai bersama-sama dari kapabilitas, wawasan, kepakaran, pengalaman hidup, serta stimulus. Human capital dapat didefinisikan sebagai keterampilan (skills), pengetahuan (knowledge), dan pengalaman (experience) individu atau populasi. Dilihat dari segi nilai atau biaya suatu organisasi. Nilai perusahaan modern ada dalam bentuk tidak berwujud (intangibles) yang sebagian besar merupakan sumber daya manusia dalam satu atau lain bentuk (Abdillah, 2020).

Terdapat beberapa faktor kesuksesan seorang wanita yang bisa dijadikan dasar penelitian ini, didasarkan pada penelitian terdahulu antara lain adalah faktor diskriminasi (Abu-Asbah dan Heilbrunn, 2011), (Al-Dajani dan Marlow, 2013), faktor komitmen (Aramand, 2013; Forson, 2013; Dawson dan Henley, 2012; Canizares dan Garcia, 2010) (Al-Dajani, H. dan Marlow, 2013) (Canizares dan Garcia, 2010), Faktor motivasi (Dawson dan Henley, 2012), faktor demografi (Hattab, 2012) (Hattab, 2012),faktor akses keuangan dan faktor kapabilitas (Achmad, 2015).

Selanjutnya, ekonomi digital adalah bagian ekonomi yang didasarkan pada penggunaan dan pensinergian teknologi informasi dan komunikasi digital. Di Asia Tenggara, ekonomi digital sedang bertumbuh cepat sejalan dengan tingginya peluang pasar. Ada lima teknologi yang paling potensial mendorong tumbuh kembang ekonomi digital di wilayah Asia Tenggara, kelima hal tersebut yaitu mobile internet, big data, internet of things, automation of knowledge, serta cloud technology.(Jennex, 2017)

Struktur Penduduk Indonesia masih bisa dikatakan relatif muda, yang mana dikuasai oleh usia produktif, dengan jumlah proporsi wanita yang hampir sama dengan laki-laki berdasarkan Survey Penduduk Antar Sensus (SUPAS 2015) Jumlah penduduk Indonesia di tahun 2020 berjumlah 269,6 juta jiwa dimana banyaknya yang berjenis kelamin laki-laki 135,34 juta jiwa, lebih banyak dibanding perempuan yang jumlahnya 134,27 juta jiwa (Badan Pusat Statistik, 2015). Bergulirnya waktu mengakibatkan perubahan penduduk, serta akan adanya potensi terbentuk bonus demografi (Badan Pusat Statistik, 2018), dimana situasi keterkaitan menjangkau titik terendah pada kurun 2028 - 2031, ini bisa dijadikan kunci utama bagi Bangsa Indonesia untuk meningkatkan perekonomian dengan bersumber pada sumber daya manusia khususnya kaum milenial yang lebih ditekankan kepada para Wanita. Karena kisaran generasi milenial yang mana lahir di tahun 1980 - 2000 sebesar 33, 75\% (Badan Pusat Statistik, 2018). 
Kesiapan generasi milenial dibandingkan dengan generasi lainnya jauh lebih mumpuni dalam menghadapi perubahan zaman dengan perkembangan teknologi dalam rangka penerapan ekonomi digital seperti dewasa ini. Sehingga dengan adanya penelitian ini maka harapannya mampu memberikan kontribusi positif nantinya untuk membuat kebijakan maupun mengarahkan masyarakat khususnya para wanita berwirausaha UMKM untuk bisa memajukan UMKM-nya sehingga mampu menghasilkan situasi kondusif dengan sumber daya manusia yang cerdas dan produktif selaras dengan perkembangan teknologi, sehingga penelitian ini bisa memberikan gambaran utama dan jawaban mengenai apa yang harus dipersiapkan oleh para Wanita generasi milenial yang menggerakkan UMKM yang mana UMKM adalah investasi didalam kehidupan sosial Bangsa Indonesia dalam rangka memasuki ekonomi digital dan ledakan lansia 30 tahun mendatang. Dengan bekerja keras didukung dengan terpenuhinya faktor-faktor sukses peran Wanita berwirausaha UMKM maka akan menuai hasilnya ketika sudah memasuki masa tuanya nanti (Badan Pusat Statistik, 2018). Indonesia juga sudah memasuki Masyarakat Ekonomi ASEAN (MEA), pergerakan sumber daya maupun produk dan jasa akan jauh lebih transparan lagi, sehingga mendorong kita untuk terus meningkatkan kemampuan, keahlian untuk tetap bertahan hidup di era ekonomi digital.

\section{Metode Penelitian}

Jenis penelitian ini adalah kuantitatif dengan menggunakan teknik analisis partial least square structural equation modelling. Objek penelitian ini respondennya adalah para wanita pengusaha UMKM diwilayah KEPRI sebanyak 110 responden. Pengambilan sampel dilakukan dengan sistem purposive sampling serta dengan cara menyebarkan kuesioner secara online menggunakan google form dengan menggunakan pilihan alternatif jawaban responden 4 skala likert. Analisis hasil penelitian menggunakan uji Partial Least Square (PLS) untuk menguji pengaruh antar variabel Diskriminasi (X1), Komitmen (X2), Motivasi (X3), Demografi (X4), Akses Keuangan (X5), Kapabilitas (Y1), Human capital UMKM (Y2), dan Ekonomi Digital (Y3).

\section{Hasil}

\section{Hasil Uji Outer Model}

Analisis outer model dilakukan untuk menguatkan bahwa pengukurun yang diterapkan wajar untuk digunakan sebagai pengukuran (valid dan reliabel). pada analisis model ini mengkhususkan keterkaitan antara variabel laten dengan indikator-indikatornya. Hasil pengujian outer model meliputi uji validitas konvergen, validitas diskriminan, dan reliabilitas konstruk(Solimun, 2010).

Convergent Validity adalah indikator yang dinilai berlandaskan hubungan antara item score/component score dengan construct score, yang bisa dilihat dari standardized loading factor yang mana mendeskripsikan tingginya hubungan antar setiap bagian pengukuran (indikator) dengan konstruknya. Skala atau refleksif individual disebutkan tinggi bila berhubungan $>0.7$ dengan konstruk yang ingin dinilai, sedangkan menurut Chin yang diambil oleh Imam Ghozali, nilai outer loading antara 0,5-0,6 sudah dikategorikan cukup. Seluruh indikator pada penelitian ini dinyatakan valid (Gambar 3).

Discriminant Validity adalah bentuk penilaian dengan pencerminan indikator dinilai berlandaskan crossloading pengukuran dengan konstruk. Bila hubungan konstruk dengan item penilaian lebih besar daripada ukuran konstruk lainnya, maka memiliki arti ukuran blok mereka lebih baik dibandingkan dengan blok lainnya. Sedangkan menurut metode lain untuk menilai discriminant validity yaitu dengan membandingkan nilai squareroot of average variance extracted (AVE). Semua indikator dinyatakan sudah memenuhi validitas diskriminan (Gambar 3).

Composite reliability adalah parameter untuk menilai suatu konstruk yang bisa diketahui di view latent variable coefficients. Untuk menilai composite reliability ada dua alat pengukuran yaitu internal consistency dan cronbach's alpha. Pada pengukuran tersebut jika skor yang dihasilkan adalah $>0,70$ sehingga bisa disebut bahwa konstruk tersebut mempunyai reliabilitas yang tinggi. Cronbach's Alpha adalah uji reliabilitas yang dilakukan memperkuat hasil dari composite reliability. Suatu variable bisa disebut reliabel jika mempunyai skor cronbach's alpha $>0,60$. Nilai hasil pengujian semua indikator sudah dinyatakan memenuhi reliabilitas konstruk (Gambar 3). 
Gambar 3. Model Penelitian dengan Partial Least Square (PLS)-SEM.

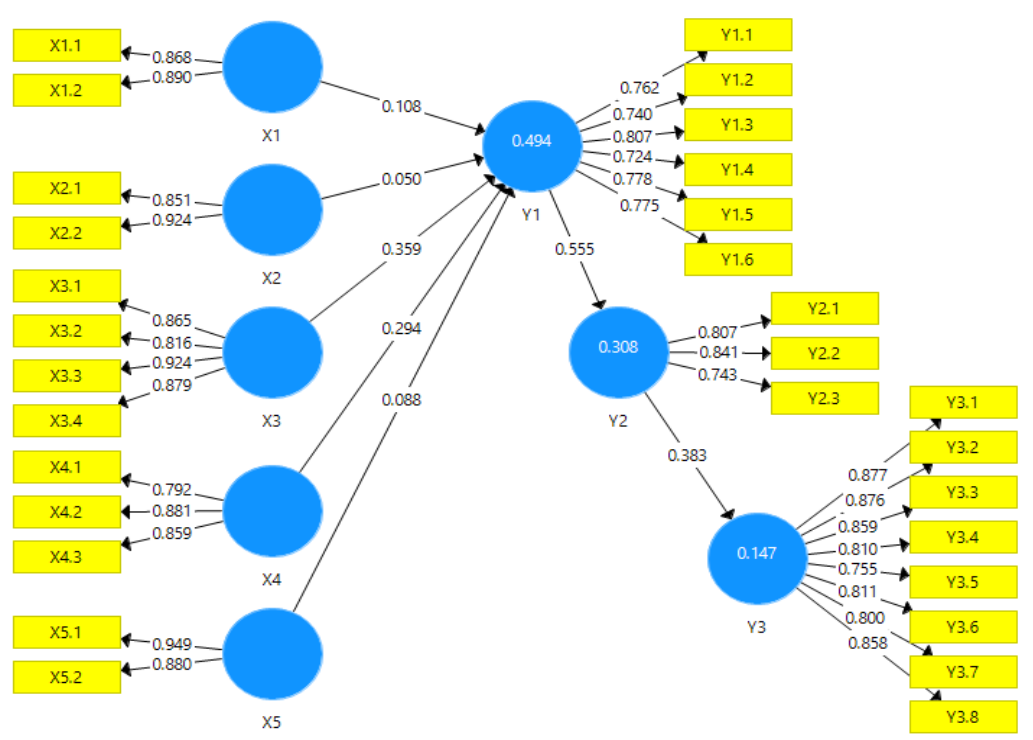

Sumber : Data Diolah (2021)

\section{Hasil Uji Inner Model}

Analisis inner model umumnya juga disebut dengan inner relation, structural model dan substantive theory yang mana mendeskripsikan keterkaitan antara variabel laten dilandaskan pada substantive theory. Analisis inner model bisa dinilai yaitu dengan menggunakan $R$-square untuk konstruk dependen, Stone-Geisser Q-square test untuk predictive relevance dan uji t serta signifikansi dari koefisien parameter jalur struktural. Pada penilaian inner model dengan PLS dimulai dengan cara mengamati $R$-square untuk setiap variabel laten dependen. Setelah itu dalam pembahasan hasilnya serupa dengan penjelasan pada regresi. Peralihan score di $R$-square bisa diterapkan untuk menilai hubungan dampak variabel laten independen tertentu terhadap variabel laten dependen apakah mempunyai dampak yang substantif. Hasil analisis inner model mencakup nilai koefisien determinasi (R-square) (Ghozali, 2008)

Tabel 4. Hasil Koefisien Determinasi

\begin{tabular}{lccc}
\multicolumn{1}{c}{ Variabel } & Variabel Endogen & R-Square & Adjusted R-Square \\
\hline Diskriminasi, Komitmen, Motivasi, & Kapabilitas & 0,494 & 0,471 \\
$\begin{array}{l}\text { Demografi, Akses Keuangan } \\
\text { Kapabilitas }\end{array}$ & Human Capital & 0,308 & 0,302 \\
Human Capital & Ekonomi Digital & 0,147 & 0,139 \\
\hline
\end{tabular}

Sumber : Data Diolah (2021)

Berdasarkan tabel 4, dapat disimpulkan bahwa kapabilitas (Y1) dipengaruhi oleh Diskriminasi (X1), Komitmen (X2), Motivasi (X3), Demografi (X4), Akses Keuangan (X5) sebesar 49,4 persen sedangkan sisanya dijelaskan oleh variabel lain. Hasil koefisien determinasi pengaruh antara dampak Kapabilitas (Y1) terhadap Human capital UMKM (Y2) diperoleh nilai r square sebesar 0,308 yang artinya pengaruh terhadap Human capital UMKM (Y2) dapat dijelaskan sebesar 30,8 persen oleh dampak Kapabilitas (Y1), sedangkan sisanya dijelaskan oleh variabel lain. Hasil koefisien determinasi pengaruh antara Human capital UMKM (Y2) terhadap Ekonomi Digital (Y3) diperoleh nilai $r$ square sebesar 0,147 yang artinya pengaruh terhadap Ekonomi Digital (Y3) dapat dijelaskan sebesar 14,7 persen oleh Human capital UMKM (Y2), sedangkan sisanya dijelaskan oleh variabel lain.

Pada pengujian hipotesis bisa diketahui dari skor t-statistik serta skor probabilitas. Untuk analisis hipotesis menggunakan nilai statistik untuk alpha $5 \%$, maka nilai t-statistik yang dipakai adalah 1,645. Sehingga golongan penerimaan atau penolakan hipotesis adalah $\mathrm{Ha}$ diterima dan $\mathrm{HO}$ di tolak ketika t-statistik $>1,645$. Untuk menolak/menerima hipotesis menggunakan probabilitas maka Ha di terima jika nilai $p<0,05$. Pada data empirik 
yang dipakai dalam penelitian ini bisa dilakukan pengujian terhadap hipotesis yang diusulkan. Di bawah ini ditampilkan hasil pengujian hipotesis berlandaskan score koefisien jalur dan T-Statistik / P-value.

Tabel 5. Hasil Pengujian Hipotesis

\begin{tabular}{|c|c|c|c|c|c|c|}
\hline Hipotesis & Pengaruh & Koef.Jalur & Stdev & T-Hitung & P-Value & Keterangan \\
\hline 1 & $\mathrm{X} 1 \rightarrow \mathrm{Y} 1$ & 0,108 & 0,066 & 1,648 & 0,050 & Signifikan \\
\hline 2 & $X 2 \rightarrow Y 1$ & 0,050 & 0,106 & 0,477 & 0,317 & Tidak Signifikan \\
\hline 3 & $X 3 \rightarrow Y 1$ & 0,359 & 0,118 & 3,057 & 0,001 & Signifikan \\
\hline 4 & $\mathrm{X} 4 \rightarrow \mathrm{Y} 1$ & 0,294 & 0,135 & 2,173 & 0,015 & Signifikan \\
\hline 5 & $X 5 \rightarrow Y 1$ & 0,088 & 0,075 & 1,165 & 0,122 & Tidak Signifikan \\
\hline 6 & $\mathrm{Y} 1 \rightarrow \mathrm{Y} 2$ & 0,555 & 0,075 & 7,432 & 0,000 & Signifikan \\
\hline 7 & $Y 2 \rightarrow Y 3$ & 0,383 & 0,110 & 3,499 & 0,000 & Signifikan \\
\hline 8 & $\mathrm{X} 1 \rightarrow \mathrm{Y} 1 \rightarrow \mathrm{Y} 2$ & 0,060 & 0,039 & 1,553 & 0,060 & Tidak Signifikan \\
\hline 9 & $\mathrm{X} 2 \rightarrow \mathrm{Y} 1 \rightarrow \mathrm{Y} 2$ & 0,028 & 0,059 & 0,471 & 0,319 & Tidak Signifikan \\
\hline 10 & $\mathrm{X} 3 \rightarrow \mathrm{Y}_{1} \rightarrow \mathrm{Y}_{2}$ & 0,199 & 0,069 & 2,884 & 0,002 & Signifikan \\
\hline 11 & $X 4 \rightarrow Y 1 \rightarrow Y 2$ & 0,163 & 0,082 & 1,999 & 0,023 & Signifikan \\
\hline 12 & $X 5 \rightarrow Y 1 \rightarrow Y 2$ & 0,049 & 0,042 & 1,169 & 0,122 & Tidak Signifikan \\
\hline 13 & $\mathrm{X}_{1} \rightarrow \mathrm{Y}_{1} \rightarrow \mathrm{Y}_{2} \rightarrow \mathrm{Y}_{3}$ & 0,023 & 0,019 & 1,217 & 0,112 & Tidak Signifikan \\
\hline 14 & $X_{2} \rightarrow Y_{1} \rightarrow Y_{2} \rightarrow Y_{3}$ & 0,011 & 0,025 & 0,422 & 0,337 & Signifikan \\
\hline 15 & $\mathrm{X} 3 \rightarrow \mathrm{Y} 1 \rightarrow \mathrm{Y} 2 \rightarrow \mathrm{Y}_{3}$ & 0,076 & 0,039 & 1,958 & 0,025 & Tidak Signifikan \\
\hline 16 & $\mathrm{X} 4 \rightarrow \mathrm{Y} 1 \rightarrow \mathrm{Y} 2 \rightarrow \mathrm{Y} 3$ & 0,063 & 0,045 & 1,389 & 0,083 & Tidak Signifikan \\
\hline 17 & $\mathrm{X}_{5} \rightarrow \mathrm{Y}_{1} \rightarrow \mathrm{Y}_{2} \rightarrow \mathrm{Y}_{3}$ & 0,019 & 0,019 & 0,972 & 0,166 & Tidak Signifikan \\
\hline 18 & $Y 1 \rightarrow Y 2 \rightarrow Y 3$ & 0,213 & 0,085 & 2,494 & 0,006 & Signifikan \\
\hline
\end{tabular}

Sumber : Data Diolah (2021)

\section{Pembahasan}

\section{Pengaruh Diskriminasi terhadap Kapabilitas}

Hipotesis pengaruh antara Diskriminasi $(X 1)$ terhadap Kapabilitas $(Y 1)$ didapat koefisien jalur sejumlah 0,108 dengan nilai $t$ statistik $1,648(t \geq 1,645)$ serta $p$-value sejumlah $0,050(p \leq 0,05)$ sehingga Diskriminasi $(X 1)$ mempunyai dampak positif dan signifikan pada Kapabilitas (Y1), artinya semakin meningkatnya Diskriminasi (X1) akan berpengaruh terhadap semakin meningkatnya Kapabilitas (Y1). Hasil memiliki arti bahwa hipotesis diterima. Budaya persamaan gender dan dukungan dari lingkungan sekitar yang memberikan kesempatan seorang pengusaha wanita untuk berkarya akan menambah keunggulan UMKM tersebut, meski tidak bisa dipungkiri selalu ada persaingan antara UMKM yang satu dengan yang lainnya, terutama para pelaku UMKM yang statusnya menjadi pendatang baru, Namun persaingan sehat akan terus mampu mendorong kapabilitas UMKM ke arah yang lebih baik dalam peningkatan kemampuan manajerial UMKM.

\section{Pengaruh Komitmen terhadap Kapabilitas}

Hipotesis pengaruh antara Komitmen (X2) terhadap Kapabilitas (Y1) didapat koefisien jalur sejumlah 0,050 dengan score $t$ statistik 0,477 ( $t<1,645)$ dan $p$-value sejumlah $0,317(p>0,05)$ sehingga Komitmen $(X 2)$ mempunyai dampak positif namun tidak signifikan pada Kapabilitas (Y1), artinya semakin tinggi atau meningkatnya Komitmen (X2) tidak akan berpengaruh pada Kapabilitas (Y1). Hasil tersebut menunjukkan bahwa hipotesis ditolak. Alasan mendirikan UMKM adalah sebagai salah satu wujud dari pengaplikasian pada program suksesi pemberdayaan wanita, dan bertujuan untuk membiayai keluarga mereka. Meski sebesar $83 \%$ dari responden statusnya belum menikah, namun mereka mendirikan UMKM tersebut sebagai penopang perekonomian keluarga sehingga untuk fokus ke profit saja. Dalam hal ini ditemukan fenomena bahwa komunitas pengusaha terutama pengusaha wanita, belum mampu memfasilitasi UMKM yang berada di bawah naungannya untuk memberikan upgrade skill dalam hal manajerial maupun networking yang mampu menambah kemampuan UMKM sehingga lebih mampu berdaya saing nantinya. IImu kewirausahaan ini perlu lebih lagi, mengingat para pelaku UMKM dengan background pendidikan lulusan SMA mayoritas.

\section{Pengaruh Motivasi terhadap Kapabilitas}

Hipotesis pengaruh antara Motivasi (X3) terhadap Kapabilitas ( $Y 1)$ didapat koefisien jalur sejumlah 0,359 dengan score $t$ statistik $3,057(t \geq 1,645)$ dan $p$-value sejumlah $0,001(p \leq 0,05)$ sehingga Motivasi $(X 3)$ mempunyai pengaruh positif dan signifikan pada Kapabilitas (Y1), artinya semakin tinggi atau meningkatnya Motivasi $(\mathrm{X} 3)$ akan berpengaruh pada semakin tinggi atau meningkatnya Kapabilitas (Y1). Hasil tersebut menunjukkan bahwa 
hipotesis diterima. Motivasi seseorang membuka bisnis, didukung oleh bakat dalam menjalankan usahanya dengan kemampuan manajerial, membaca kondisi pasar, menganalisis setiap peluang yang dimilikinya yang semuanya itu berasal dari pengetahuan kewirausahaan yang dimilikinya, sehingga dengan kemampuan ilmu berwirausaha yang semakin baik tentunya akan meningkatkan kemampuan seseorang dalam mengoperasikan UMKM tersebut.

\section{Pengaruh Demografi terhadap Kapabilitas}

Hipotesis pengaruh antara Demografi $(X 4)$ terhadap Kapabilitas (Y1) didapat koefisien jalur sejumlah 0,294 dengan nilai $t$ statistik 2,173 ( $t \geq 1,645)$ dan $p$-value sejumlah $0,015(p \leq 0,05)$ sehingga Demografi $(X 4)$ mempunyai dampak positif dan signifikan pada Kapabilitas ( $Y 1)$, artinya semakin tinggi dan meningkatnya Demografi (X4) akan berpengaruh terhadap semakin tinggi atau meningkatnya Kapabilitas (Y1). Hasil tersebut memiliki arti bahwa hipotesis diterima. Mengelola sebuah UMKM harus totalitas dari sisi penggunaan waktu, semakin banyak ketersediaan waktu, maka dengan dasar pengalaman maupun pengetahuan si pemilik UMKM akan mampu menambah kapabilitas dari UMKM tersebut.

\section{Pengaruh Akses Keuangan terhadap Kapabilitas}

Hipotesis pengaruh antara Akses Keuangan (X5) terhadap Kapabilitas (Y1) diperoleh koefisien jalur sebesar 0,088 dengan nilai $t$ statistik $1,165(t<1,645)$ dan $p$-value sebesar $0,122(p>0,05)$ sehingga Akses Keuangan (X5) memiliki pengaruh positif namun tidak signifikan terhadap Kapabilitas (Y1), artinya semakin baik Akses Keuangan (X5) tidak akan berpengaruh terhadap Kapabilitas (Y1). Hasil tersebut menunjukkan bahwa hipotesis ditolak. Mayoritas bisnis UMKM di Kepri ini, yang hampir keseluruhan respondennya lokasi usahanya di Kota Batam sebesar 96\%, Kabupaten Karimun sebanyak 3\% dan Kota Tanjung Pinang sebanyak 1\%. Mereka semua mendanai bisnisnya berasalkan dari modal pribadi, hal ini dikarenakan sulitnya akses pembiayaan untuk permodalan bisnis. Hal inilah yang mengakibatkan dari sisi permodalan UMKM secara kapabilitas belum mampu memberikan sumbangsih signifikan perkembangannya. Karena dana yang dimiliki terbatas hanya berasal dari sang pemilik UMKM saja. Kesulitan pembiayaan juga bisa saja terjadi akibat kondisi pandemic covid-19. Dan mayoritas UMKM tersebut baru berdiri sekitar 1-5 tahun. Sehingga rekam jejaknya belum terlihat jelas, hal ini juga bisa mempengaruhi dari keputusan pemberian kredit oleh pihak pembiayaan.

\section{Pengaruh Kapabilitas terhadap Human Capital UMKM}

Hipotesis pengaruh antara Kapabilitas (Y1) terhadap Human capital UMKM (Y2) diperoleh koefisien jalur sebesar $0,555$ dengan nilai t statistik 7,432 ( $t \geq 1,645)$ dan $p$-value sebesar $0,000(p \leq 0,05)$ sehingga Kapabilitas $(Y 1)$ memiliki pengaruh positif dan signifikan terhadap Human capital UMKM (Y2), artinya semakin baik Kapabilitas (Y1) akan berpengaruh terhadap semakin baik Human capital UMKM (Y2). Hasil tersebut menunjukkan bahwa hipotesis diterima. Kemampuan manajerial yang baik seperti inovasi dan kreatifitas yang mendorong UMKM mampu beradaptasi dengan keadaan yang tidak pasti dan didukung dengan networking yang baik, proaktif terhadap perkembangan teknologi, serta menjaga hubungan baik dengan customer dan menjadi good planner dalam usahanya, hal-hal inilah yang akan mendorong UMKM sebagai wadah yang memberikan nilai lebih kepada lingkungan sosial ekonomi dalam ruang lingkup bernegara yang terukur dari profitable yang cukup baik sehingga mampu membayar utang yang jatuh tempo dan tetap memaintance customer yang loyal dengan sangat memperhatikan zero complaint.

\section{Pengaruh Human Capital UMKM terhadap Ekonomi Digital}

Hipotesis pengaruh antara Human capital UMKM (Y2) terhadap Ekonomi Digital (Y3) diperoleh koefisien jalur sebesar 0,383 dengan nilai t statistik 3,499 ( $t \geq 1,645)$ dan $p$-value sebesar $0,000(p \leq 0,05)$ sehingga Human capital UMKM (Y2) memiliki pengaruh positif dan signifikan terhadap Ekonomi Digital (Y3), artinya semakin baik Human capital UMKM (Y2) akan berpengaruh terhadap semakin baik Ekonomi Digital (Y3). Hasil tersebut menunjukkan bahwa hipotesis diterima. Tingginya kemampuan para pemilik UMKM dalam mengembangkan dan mengelola bisnisnya di era ekonomi digital ini, pasti akan mendorong mereka menerapkan digitalisasi dalam kegiatan operasional UMKM tersebut, hal juga didorong karena pemilik UMKM tersebut dari generasi millenial itu merupakan kaum yang sangat melek terhadap teknologi digitalisasi. 


\section{Pengaruh Diskriminasi terhadap Human capital UMKM melalui Kapabilitas}

Hipotesis pengaruh antara Diskriminasi (X1) terhadap Human capital UMKM (Y2) melalui Kapabilitas (Y1) didapat koefisien jalur sejumlah 0,060 dengan nilai t statistik $1,553(t<1,645)$ dan $p$-value sejumlah $0,060(p>$ $0,05)$ sehingga Diskriminasi $(X 1)$ mempunyai pengaruh positif namun tidak signifikan pada Human capital UMKM (Y2) melalui Kapabilitas (Y1), artinya semakin baik Diskriminasi (X1) tidak akan berpengaruh terhadap Human capital UMKM (Y2) melalui Kapabilitas (Y1). Hasil tersebut menunjukkan bahwa hipotesis ditolak.

\section{Pengaruh Komitmen terhadap Human Capital UMKM melalui Kapabilitas}

Hipotesis pengaruh antara Komitmen (X2) terhadap Human capital UMKM (Y2) melalui Kapabilitas (Y1) didapatkan koefisien jalur adalah 0,028 dengan nilai $t$ statistik $0,471(t<1,645)$ dan $p$-value adalah $0,319(p>$ 0,05 ) sehingga hasilnya Komitmen (X2) mempunyai pengaruh positif namun tidak signifikan pada Human capital UMKM (Y2) melalui Kapabilitas (Y1), artinya semakin baik Komitmen (X2) tidak akan berpengaruh terhadap Human capital UMKM (Y2) melalui Kapabilitas (Y1). Hasil tersebut menunjukkan bahwa hipotesis ditolak.

\section{Pengaruh Motivasi terhadap Human capital UMKM melalui Kapabilitas}

Hipotesis pengaruh antara Motivasi (X3) terhadap Human capital UMKM (Y2) melalui Kapabilitas (Y1) dihasilkan koefisien jalur yaitu 0,199 dengan score $t$ statistik 2,884 ( $t \geq 1,645)$ serta $p$-value sebesar $0,002(p \leq 0,05)$ sehingga Motivasi (X3) memiliki pengaruh positif dan signifikan pada Human capital UMKM (Y2) melewati Kapabilitas (Y1), artinya semakin baik Motivasi (X3) akan berpengaruh pada semakin baik Human capital UMKM (Y2) melalui Kapabilitas (Y1). Hasil tersebut menunjukkan bahwa hipotesis diterima.

\section{Pengaruh Demografi terhadap Human capital UMKM melalui Kapabilitas}

Hipotesis pengaruh antara Demografi (X4) terhadap Human capital UMKM (Y2) melalui Kapabilitas (Y1) dihasilkan koefisien jalur adalah 0,163 dengan score $t$ statistik $1,999(t \geq 1,645)$ serta $p$-value adalah $0,023(p \leq$ $0,05)$ sehingga Demografi $(X 4)$ mempunyai pengaruh positif serta signifikan pada Human capital UMKM (Y2) melalui Kapabilitas (Y1), artinya semakin baik Demografi (X4) akan berpengaruh pada semakin baik Human capital UMKM (Y2) melalui Kapabilitas (Y1). Hasil tersebut mendiskripsikan bahwa hipotesis diterima.

\section{Pengaruh Akses Keuangan terhadap Human capital UMKM melalui Kapabilitas}

Hipotesis pengaruh antara Akses Keuangan (X5) terhadap Human capital UMKM (Y2) melalui Kapabilitas (Y1) dihasilkan koefisien jalur sebesar 0,049 dengan nilai t statistik 1,169 $(t<1,645)$ dan $p$-value sejumlah 0,122 ( $p>$ 0,05 ) sehingga Akses Keuangan (X5) memiliki pengaruh positif namun tidak signifikan terhadap Human capital UMKM (Y2) melalui Kapabilitas (Y1), artinya semakin baik Akses Keuangan (X5) tidak akan berpengaruh terhadap Human capital UMKM (Y2) melalui Kapabilitas (Y1). Hasil tersebut menunjukkan bahwa hipotesis ditolak.

Secara umum, diskriminasi, komitmen, Akses keuangan berpengaruh positif tidak signifikan terhadap Human capital UMKM melalui Kapabilitas. Kemampuan dari sebuah UMKM tergolong baik ataupun tidak bisa dipengaruhi secara langsung oleh diskriminasi, komitmen maupun akses keuangan. Karena segala hal untuk mengukur Human capital UMKM pada kemampuan profitabilitynya dan penguasaan penangan customer complain. Sehingga faktor diskriminasi adalah penyebab faktor eksternal yang tidak akan mempengaruhi keadaan UMKM, apalagi di Wilayah Kepri sudah menganut budaya yang menyetarakan gender, meski persaingan antara pendatang baru dan pendatang lama pasti terjadi, ini merupakan hal yang wajar terjadi. Akses keuangan juga tidak berpengaruh, karena pengukuran untuk Human capital UMKM didasarkan pada solvabilitasnya, dan mayoritas UMKM didanai oleh dana sendiri atau pribadi dari sisi permodalannya.

\section{Pengaruh Diskriminasi terhadap Ekonomi Digital melalui Kapabilitas dan Human capital UMKM}

Hipotesis pengaruh antara Diskriminasi (X1) terhadap Ekonomi Digital (Y3) melalui Kapabilitas (Y1) dan Human capital UMKM (Y2) diperoleh koefisien jalur sebesar 0,023 dengan nilai t statistik 1,217 ( $t<1,645)$ serta $p$-value sebesar $0,112(p>0,05)$ sehingga Diskriminasi $(X 1)$ memiliki pengaruh positif namun tidak signifikan terhadap Ekonomi Digital (Y3) melalui Kapabilitas (Y1) dan Human capital UMKM (Y2), artinya semakin baik Diskriminasi (X1) tidak akan berpengaruh terhadap Ekonomi Digital (Y3) melalui Kapabilitas (Y1) dan Human capital UMKM (Y2). Hasil tersebut menunjukkan bahwa hipotesis ditolak. 


\section{Pengaruh Komitmen terhadap Ekonomi Digital melalui Kapabilitas dan Human Capital UMKM}

Hipotesis pengaruh antara Komitmen (X2) terhadap Ekonomi Digital (Y3) melalui Kapabilitas (Y1) dan Human capital UMKM (Y2) dihasilkan koefisien jalur sebesar 0,011 dengan nilai t statistik 0,422 $(t<1,645)$ serta $p$-value sebesar 0,337 ( $p>0,05)$ sehingga Komitmen (X2) memiliki pengaruh positif namun tidak signifikan pada Ekonomi Digital (Y3) melewati Kapabilitas (Y1) dan Human capital UMKM (Y2), artinya semakin baik Komitmen (X2) tidak akan berpengaruh terhadap Ekonomi Digital (Y3) melalui Kapabilitas (Y1) dan Human capital UMKM (Y2). Hasil tersebut menunjukkan bahwa hipotesis ditolak.

\section{Pengaruh Motivasi terhadap Ekonomi Digital melalui Kapabilitas dan Human Capital UMKM}

Hipotesis pengaruh antara Motivasi (X3) terhadap Ekonomi Digital (Y3) melalui Kapabilitas (Y1) dan Human capital UMKM (Y2) diperoleh koefisien jalur sebesar 0,076 dengan nilai $t$ statistik 1,958 ( $t \geq 1,645)$ dan $p$-value sebesar $0,025(p \leq 0,05)$ sehingga Motivasi $(X 3)$ memiliki pengaruh positif dan signifikan terhadap Ekonomi Digital (Y3) melalui Kapabilitas (Y1) dan Human capital UMKM (Y2), artinya semakin tinggi Motivasi (X3) akan berdampak pada semakin tingginya Ekonomi Digital (Y3) melalui Kapabilitas (Y1) dan Human capital UMKM (Y2). Hasil tersebut menunjukkan bahwa hipotesis diterima.

\section{Pengaruh Demografi terhadap Ekonomi Digital melalui Kapabilitas dan Human capital UMKM}

Hipotesis pengaruh antara Demografi (X4) terhadap Ekonomi Digital (Y3) melalui Kapabilitas (Y1) dan Human capital UMKM (Y2) didapatkan koefisien jalur adalah 0,063 dengan nilai t statistik 1,389 $(\mathrm{t}<1,645)$ serta $\mathrm{p}$-value sejumlah 0,083 $(p>0,05)$ artinya Demografi $(X 4)$ mempunyai pengaruh positif namun tidak signifikan terhadap Ekonomi Digital (Y3) melalui Kapabilitas (Y1) dan Human capital UMKM (Y2), artinya semakin baik Demografi (X4) tidak akan berpengaruh terhadap Ekonomi Digital (Y3) melalui Kapabilitas (Y1) dan Human capital UMKM (Y2). Hasil tersebut menunjukkan bahwa hipotesis ditolak.

\section{Pengaruh Akses Keuangan terhadap Ekonomi Digital melalui Kapabilitas dan Human Capital UMKM}

Hipotesis pengaruh antara Akses Keuangan (X5) terhadap Ekonomi Digital (Y3) melalui Kapabilitas (Y1) dan Human capital UMKM (Y2) diperoleh koefisien jalur sebesar 0,019 serta score t statistik 0,972 $(t<1,645)$ dan $p$ value sebesar 0,166 ( $p>0,05)$ jadi artinya adalah Akses Keuangan (X5) mempunyai pengaruh positif namun tidak signifikan pada Ekonomi Digital (Y3) melalui Kapabilitas (Y1) dan Human capital UMKM (Y2), artinya semakin baik Akses Keuangan (X5) tidak akan berpengaruh terhadap Ekonomi Digital (Y3) melalui Kapabilitas (Y1) dan Human capital UMKM (Y2). Hasil tersebut menunjukkan bahwa hipotesis ditolak.

\section{Pengaruh Kapabilitas terhadap Ekonomi Digital melalui Human capital UMKM}

Hipotesis pengaruh antara Kapabilitas (Y1) terhadap Ekonomi Digital (Y3) melalui Human capital UMKM (Y2) diperoleh koefisien jalur sebesar 0,213 dengan nilai t statistik 2,494 ( $t \geq 1,645)$ dan $p$-value sebesar 0,006 ( $p \leq$ 0,05 ) jadi artinya adalah Kapabilitas (Y1) memiliki dampak hubungan positif serta signifikan terhadap Ekonomi Digital (Y3) melewati Human capital UMKM (Y2), artinya makin baik nilai aspek Kapabilitas (Y1) akan berpengaruh terhadap makin baiknya aspek Ekonomi Digital (Y3) melalui Human capital UMKM (Y2). Hasil tersebut menjelaskan bahwa hipotesis diterima.

Secara umum, diskriminasi, komitmen, demografi, dan akses keuangan berpengaruh positif tidak signifikan terhadap ekonomi digital melalui kapabilitas dan Human capital UMKM. Ekonomi digital tercipta dengan baik di UMKM di Wilayah Kepri, karena rata-rata yang mengoperasikan dan memiliki UMKM adalah para wanita yang khususnya berasal dari generasi milenial yang sudah melek terhadap teknologi digital, mereka hidup di zaman tersebut, segala macam kendala diskriminasi, dukungan dari komunitas yang terlihat kurang maksimal dan kemampuan berbisnis yang otodidak mereka pelajari dari bangku pendidikan, keluarga, maupun pengalaman pribadi, dan permodalan UMKM yang didanai oleh dana pribadi, tidak mempengaruhi pengaplikasian atau keputusan seseorang pemilik UMKM untuk terlibat dalam ekonomi digital, fasilitas digital, mereka gunakan memang karena mereka mampu mengoperasikannya, mereka hidup di zaman digital, serta fasilitas digitalnya salah satu solusi dari permasalahan kesulitan perekonomian akibat pandemi dewasa ini, supaya UMKM tetap maju dan berkembang. 


\section{Kesimpulan}

Maka dari hasil olah data penelitian ini, kita bisa tarik kesimpulan bahwa faktor diskriminasi (X1), motivasi (X3) dan demografi (X4) berpengaruh positif signifikan terhadap kapabilitas, sedangkan faktor komitmen (X2) dan akses keuangan (X5) berpengaruh positif namun tidak signifikan. Faktor kapabilitas (Y1) berpengaruh positif signifikan terhadap Human capital UMKM (Y2), dan faktor Human Capital UMKM (Y2) berpengaruh positif signifikan terhadap ekonomi digital (Y3).

Dalam menciptakan UMKM yang unggul dan berdaya saing, terutama UMKM yang dimiliki wanita, faktor budaya kesetaraan gender itu harus menjadi landasan utama dalam menjalankan UMKM, wanita harus diperlakukan sama dengan pria dalam hal berkarya maupun berbisnis, dukungan dari keluarga, dukungan dari komunitas pengusaha daerah, maupun dari pemerintah memberikan kontribusi positif pada tumbuh kembang UMKM, namun fenomena yang didapat di wilayah Kepri, komunitas pengusaha wanita yang dikelola swasta belum mampu memberikan kontribusi positif yang signifikan terhadap peningkatan pengetahuan dan skill para anggotanya, komunitas tersebut begitu isolatif terhadap ilmu pengetahuan kewirausahaan yang berasal dari luar komunitasnya. Pada ilmu kewirausahaan seharusnya didapat dari mana saja. Bukan hanya dari ruang lingkup internal komunitas saja. Begitu juga dengan akses keuangan yang rata-rata masih menggunakan modal pribadi, akibat adanya kesulitan dalam memperoleh akses pembiayaan bisa jadi lembaga pembiayaan atau perbankan masuk dalam fase yang lebih selektif akibat pandemic covid -19 dan didukung dengan rekam jejak pelaku usaha yang umur bisnisnya rata-rata baru 1-5 tahun lamanya

Sebagai saran, alangkah baiknya Pemerintah memberikan kesempatan terbuka lebar, terutama melalui Dinas Koperasi dan UMKM maupun Kantor Perlindungan Anak dan Pemberdayaan Perempuan untuk lebih aktif memberikan sosialisasi secara online untuk masa saat ini, mengenai ilmu kewirausahaan kepada para pelaku UMKM wanita di Kepri atau memberikan kesempatan kepada para pembicara akademisi untuk mendapatkan akses masuk ke dalam komunitas pengusaha wanita yang didirikan oleh swasta dalam rangka memberikan kesempatan dalam membantu mengsharekan ilmu kewirausahan ataupun manajerial UMKM, untuk menambah wawasan para pelaku UMKM. Serta dukungan dan peran lembaga pembiayaan lebih baik juga mendapat support dari Pemerintah supaya mampu memberikan kredit tepat guna, kepada para pelaku UMKM dalam mengembangkan usahanya. Saran untuk peneliti selanjutnya untuk menambahkan jumlah responden karena semakin banyak responden yang diteliti, secara statistik akan mampu memberikan deskripsi penelitian lebih detail dan jauh lebih baik.

\section{Ucapan Terima Kasih}

Terima kasih kepada Kementrian Pendidikan Kebudayaan Riset dan Teknologi yang telah memberikan dukungan terhadap pelaksanaan penelitian ini melalui hibah penelitian KEMENDIKBUDRISTEK Tahun Anggaran 2021.

\section{References}

Abu-Asbah, K. M. dan H. (2011). Patterns of entrepreneurship of Arab women in Israel. Journal of Enterprising Communities: People and Places in the Global Economy, 5(3), 184-198. https://www.researchgate.net/publication/227429562_Patterns_of_entrepreneurship_of_Arab_women_in_I srael/link/09e41511a42a9677ca000000/download

Achmad, N. dan E. P. S. (2017). Model Sukses Faktor Wirausaha Wanita. Jurnal Manajemen, Strategi Bisnis Dan Kewirausahaan, 11(2), 188. https://ojs.unud.ac.id

Al-Dajani, H. dan Marlow, S. (2013). Empowerment and entrepreneurship: A theoretical framework. International Journal of Entrepreneurial Behaviour \& Research., 19(5), 503-524. https://researchportal.uea.ac.uk/en/publications/empowerment-and-entrepreneurship-a-theoretical-framework

Badan Pusat Statistik. (2015). SUPAS (Survey Penduduk Antar Sensus ). Badan Pusat Statistik. www.bps.go.id

Badan Pusat Statistik. (2018). Profil Generasi Milenial, Statistik Gender Tematik (Badan Pusat Statistik (ed.)). Kementrian Pemberdayaan Perempuan dan Perlindungan Anak.

Bayu, yuyus suryana dan K. (2011). Kewirausahaan Pendekatan Karakteristik Wirausahawan Sukses (2nd ed.). Kencana.

https://books.google.co.id/books?hl=en\&lr=\&id=zKRPDwAAQBAJ\&oi=fnd\&pg=PR5\&dq=Wanita+sangat+jel i+melihat+peluang+usaha,Wanita+memang+memiliki+kelebi

Canizares, S.M.C. dan Garcla, F. J. F. (2010). Gender differences in entrepreneurial attitudes . Equality, Diversity and Inclusion. An International Journal, 29(8), 766-786. https://www.emerald.com/insight/content/doi/10.1108/02610151011089519/full/html 
Claudia Aprilinda Aluy, Joy Elly Tulung, H. H. D. T. (2017). PENGARUH KEBERADAAN WANITA DALAM MANAJEMEN PUNCAK DAN KEPEMILIKAN MANAJERIAL TERHADAP KINERJA KEUANGAN PERBANKAN (STUDI PADA BANK BUMN DAN BANK SWASTA NASIONAL DEVISA DI INDONESIA). Jurnal EMBA Universitas Sam Ratulangi Manado, 5(2), 821-828. file://C:/Users/DELL/Downloads/1599732088-1-SM.pdf

Dawson, C. dan Henley, A. (2012). "Push" versus "pull" entrepreneurship: An ambiguous distinction? International Journal of Entrepreneurial Behaviour \& Research, 18(6), 697-719. https://www.emerald.com/insight/content/doi/10.1108/13552551211268139/full/html

Elwood Carlson. (2008). The Lucky Few: Between the Greatest Generation and the Baby Boom. Florida State University.

https://books.google.com.sg/books?hl=en\&lr=\&id=zUJgaHde6YUC\&oi=fnd\&pg=PR11\&dq=Elwood+Carlso n+dalam+bukunya+yang+berjudul+The+Lucky+Few:+Between

Ghozali, I. (2008). Structural Equation Modeling: Metode Alternatif dengan Partial Least Square (PLS). Badan Penerbit Undip.

Ghozali, I. (2011). Model Persamaan Struktural: Konsep dan Aplikasi dengan Program AMOS 21.0. Badan Penerbit Undip.

Hattab, H. (2012). Towards understanding female entrepreneurship in Middle Eastern and North African countries: A cross-country comparison of female entrepreneurship. Education, Business and Society: Contemporary Middle Eastern Issues. Emerald Group Publishing Limited, 5(3), 171-186. https://www.emerald.com/insight/content/doi/10.1108/17537981211265561/full/html

Jamil, M. A. dan S. M. (2017). Eksistensi PKL Perempuan dalam Meningkatkan Pendapatan Ekonomi Keluarga Miskin. Ekonomica Sharia- Jurnal Pemikiran Dan Pengembangan Ekonomi Syariah, 2(2), 218. https://ejournal.stebisigm.ac.id/index.php/esha/article/view/94/83

Jennex, M. E. (2017). Big Data, the Internet of Things, and the Revised Knowledge Pyramid. ACM SIGMIS, 48(4), 69-79. https://dl.acm.org/doi/abs/10.1145/3158421.3158427

Leon A. Abdillah, D. (2020). Human capital Management (J. Simarmata (ed.)). yayasan kita menulis. https://books.google.co.id/books?hl=en\&lr=\&id=MlgBEAAAQBAJ\&oi=fnd\&pg=PA111\&dq=HUMAN+CAPIT AL+DEFINISI\&ots=kokyzgEtbm\&sig=smuCrrhYkJu-6xcioSQKyk

Nur Achmad S.E., M. dan E. P. S. (2015). Faktor Sukses Wirausaha Wanita. FEB Unsoed, 15(1). http://jp.feb.unsoed.ac.id/index.php/sca-1/article/view/600

Undang-Undang No. 20 Tahun 2008 tentang Usaha Mikro, Kecil, dan Menengah. Jakarta., Pub. L. No. No. 20 Tahun 2008 (2008). https://www.ojk.go.id/sustainable-finance/id/peraturan/undang-undang/Pages/UndangUndang-Republik-Indonesia-Nomor-20-Tahun-2008-Tentang-Usaha-Mikro,-Kecil,-dan-

Menengah.aspx\#: :text=Kecil\%2C dan Menengah-,Undang-Undang Nomor 20 Tahun 2008,Usaha Mikro\%2C K

Rizal, Muhammad, Dias Setianingsih, R. C. (2016). Faktor-faktor yang mempengaruhi wanita berwirausaha (Studi Kasus Kota Langsa). Jurnal Manajemen Dan Keuangan, 5(2). https://ejurnalunsam.id

Solimun. (2010). Analisis Multivariat Pemodelan Struktural: Metode Partial Least Square-PLS. CV Citra Malang.

Statistik, B. P. (2017). Produk Domestik Bruto. http://www.bps.go.id/index.php?news=730

Sutanto, P., \& Haryoko, F. (2010). Gambaran Konsep Diri pada Wanta Berkarier Sukses yang Belum Menikah. INSAN, 12(11-20). http://www.journal.unair.ac.id/filerPDF/2-12_1.pdf

Yanuar Surya Putra. (2016). THEORITICAL REVIEW : TEORI PERBEDAAN GENERASI. Among Makarti, 9(2). https://jurnal.stieama.ac.id/index.php/ama/article/view/142 